\title{
The effect of diet components on the level of cortisol
}

\author{
Marta Stachowicz $^{1} \cdot$ Anna Lebiedzińska $^{1}$
}

Received: 25 May 2016 / Accepted: 8 August 2016 / Published online: 3 September 2016

(C) The Author(s) 2016. This article is published with open access at Springerlink.com

\begin{abstract}
The way and the quality of nutrition are important factors that can have influence on behavior of both the health and well-being. Proper diet helps to maintain homeostasis in the body. Changes in lifestyle lead to increase the degree of food processing and hence reduce the nutritional value of available products. This forces the use of technological amendments in nourishment, i.e., fortification and formation of diet supplements. Modified food can complement diet in necessary nutrients. Environmental factors like activity can cause adaptation changes in endocrine system of every human. Cortisol is a corticosteroid, in which influence is varied depending on its concentration. Through its multipronged action, it mobilizes organism to fight stress, by ensuring a stable level of glucose, stimulating tissue's regeneration and inhibiting inflammation processes. Factors like stressful work, personal problems, intensive trainings can lead to long-term sustained, excessive concentration of this hormone, affecting formation of metabolic disorders such as insulin resistance, increased blood pressure, abnormal bone regeneration and collagen synthesis or calcium deficiency in the organism. Diet supplementation is currently extensively used by both healthy and unwell people, in different age, but most commonly refers to physically active people. Lots of widely available dietary supplements contain nutrients which regulate steroid hormones homeostasis. Elaboration of optimal diet is one of the agents determining well-being, health and success. In this paper, we review the current knowledge on the effect of dietary components on level of cortisol.
\end{abstract}

Anna Lebiedzińska

aleb@gumed.edu.pl

1 Department of Food Sciences, Medical University of Gdańsk, Al. Gen. J. Hallera 107, 80-416 Gdańsk, Poland
Keywords Cortisol $\cdot$ Nutrition $\cdot$ Supplementation $\cdot$ Sports · Hormonal balance

\section{Introduction}

Cortisol (hydrocortisone) is in human body the prevailing hormone from glucocorticoids group. By multidirectional acting within the physiological processes, it prepares body to physical and mental stress. It affects the metabolism of proteins, carbohydrates and fats and also participates in the regulation of water and electrolyte balance, blood pressure, body temperature, mineralization of the bones and the immune response. Additionally, it acts on mood and behavior, appetite and pain perception [1,2].

Cortisol mobilizes organism to fight stress, by affecting functioning of many organs and systems. It regulates the usage of diet nutrients through increasing gluconeogenesis and increasing lipolysis in adipose tissue. In addition, it increases protein synthesis in the liver and restricts their formation in muscles and skin cells. Furthermore, it increases retention of water and sodium, controls production of adrenaline in adrenal medulla, inhibits inflammatory processes and also affects the psyche, often provoking euphoria or depression [3].

The aim of the study is to present the current scientific views on the role of dietary components and way of nourishment on production of cortisol in the body of physically active person.

\section{Dietary components and metabolism of cortisol}

Properly composed diet provides all the nutrients derived from plants and animal products. Cholesterol is a fat-like 
Fig. 1 Endogenous synthesis and metabolism of cortisol. Own elaboration based on [1-8]

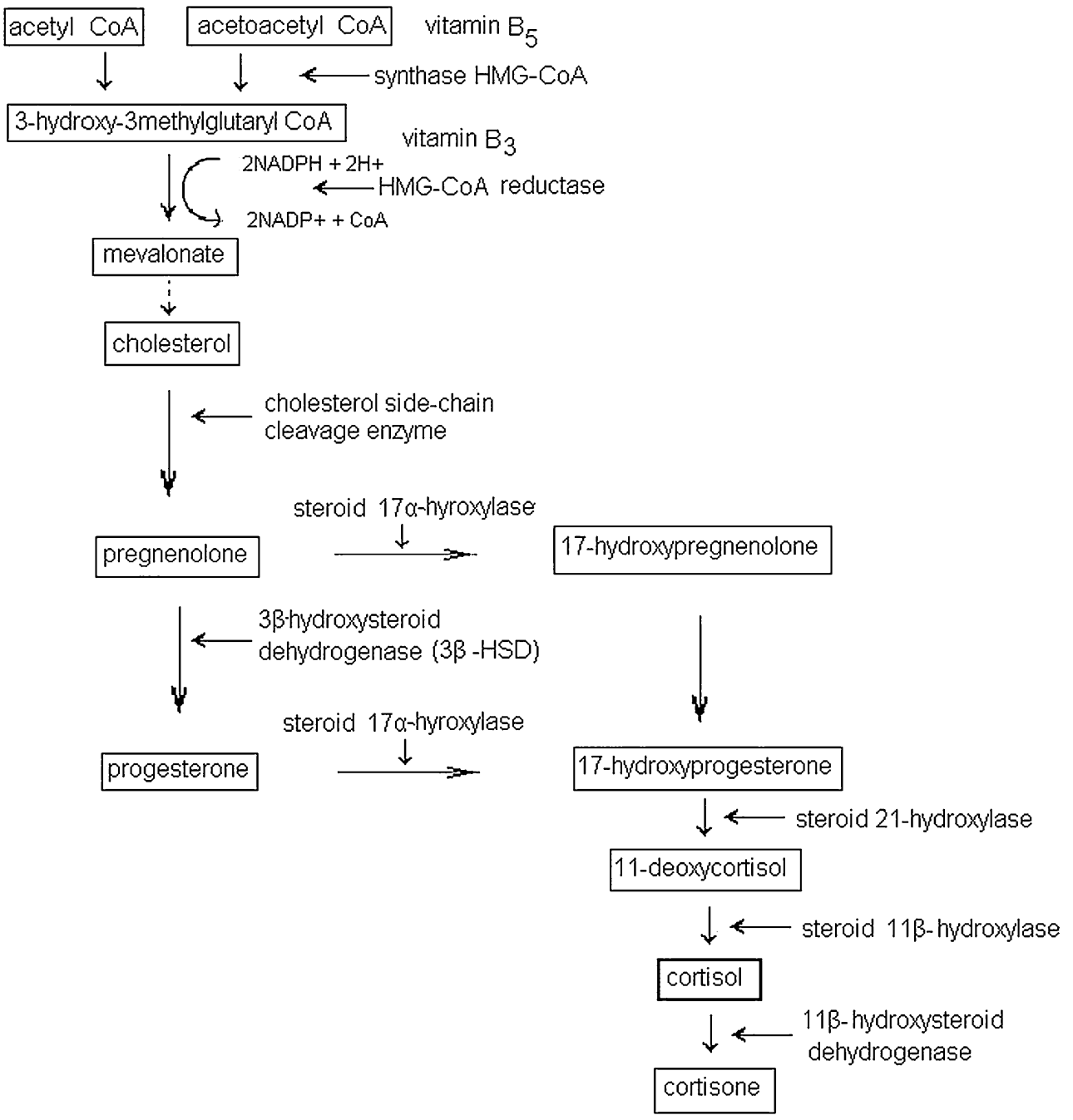

substance which occurs in animal fats and is also continuously produced in the human body. Endogenous synthesis of cholesterol starts with the condensation of three molecules of acetyl CoA. The further course of the reaction is dependent on the presence of a number of enzymes and of vitamin B3 inherence. As a result of a triple enzymatic hydroxylation of cholesterol arises cortisol (Fig. 1), which is released into the blood by passive diffusion process [1-8].

Figure 1 shows the synthesis and metabolism of cortisol including the effect of B vitamins (B3 and B5).

Metabolism of cortisol takes place mainly in the liver, where by means of reductases it is converted to tetrahydrometabolites (THMs), which are then excreted in urine. The hormone may undergo changes in the organism before it reaches the receptors in the target cells under microsomal $11 \beta$-hydroxysteroid dehydrogenase which reversibly deactivates it to cortisone [2, 7].

\section{Factors regulating production and secretion of cortisol}

Cortisol secretion is controlled by circadian rhythm, the negative external stimuli and feedback regulation, as confirmed by studies conducted by Bornstein et al. [6].

Under the influence of circadian and stress factors, hypothalamus releases corticotropin-releasing hormone (CRH) and vasopressin (ADH, antidiuretic hormone). Arising hormones stimulate the anterior pituitary gland to produce adrenocorticotropic hormone (ACTH). ACTH affects expression of StAR protein which transports cholesterol across the mitochondrial membrane and allows the process of cortisol formation in the adrenal cortex [2].

Transport of cortisol takes place in biologically inactive conjunctions with transcortin $(90 \%)$ and albumin (7\%). In target cells, it affects the transcription of DNA. In 
conducted studies, it was found that cortisol can also influence functioning of body, using non-genomic mechanisms [1-3].

The body's response to cortisol depends on its concentration and the concentration of the receptor that is affected by the state of development, timing of cell cycle and endocrine disorders [1-3].

\section{Functions of cortisol in human body}

Endocrine functions are dependent on environmental factors, including the manner and quality of diet as well as physical activity.

A number of dietary and endogenous factors affect on maintaining an appropriate level of glucose in human blood. Cortisol acts on glucose amount by activating hepatic glycogen stores, reducing the oxidation of glucose, stimulation of lipolysis and intensification of gluconeogenesis from amino acid severity. Persisting high levels of this hormone contributes to the development of insulin resistance, dyslipidemia, hypertension and obesity. Mobilization of glucose reserves is particularly important in case of rapid stress situations like endurance training due to prolonged effort [2, 7-9].

Furthermore, cortisol affects the appetite [7]. De Sa et al. demonstrated that oral administration on this substance amplified startle responsiveness during presentation of pictures of food with high glycemic index. There was not such an effect in case of normal and pleasant non-food images [10]. It was shown that injection of ghrelin, the hormone that stimulates hunger, increases levels of cortisol, ACTH and growth hormone but does not affect leptin [11].

In physiological concentrations, cortisol stimulates the synthesis of collagen. However, increasing its amount in blood stream, caused by mental stress or too intense physical effort, leads to a number of modifications within the structure of osteoblast and concentrations of chemical substances involved in process of bone remodeling. These changes bring disturbances in bone mineralization and inhibition of collagen synthesis. In addition, an excess of cortisol impairs the active transport of calcium ions across cell membranes and reduces its absorption in gastrointestinal tract, leading to calciuria [5].

Cortisol enhances sensitivity of tissues of blood vessels and heart to noradrenaline, vasopressin and angiotensin II, resulting in increased blood pressure. In addition, it affects the water and electrolyte balance, increasing retention of water and sodium $[3,7,9]$. Cortisol also acts on thermal regulation of body, to prevent overheating of organism [7].

Hydrocortisone affects the immune system, showing anti-inflammatory and immunosuppressive effects by reducing secretion of proinflammatory cytokines, by decreasing migration of white blood cells to sites of inflammation and by inducting cell apoptosis. This stimulates the body's defensive responses to injuries, including those occurring during training and sport starts $[9,12,13]$.

Cortisol influences neuronal plasticity and neurodegenerative processes by acting on neurons and glial cells within the central nervous system. In addition, it modifies mood and behavior, as well as perception of pain, which is particularly important in mobilizing player in time of starts [7].

Cortisol, which is called hormone of fight with stress, prepares athlete to increase effort. However, its excess leads to catabolic reactions, negatively affecting the organism. The concentration of cortisol, as a catabolic hormone, stays in dynamic equilibrium with anabolic hormones. It has been shown that high levels of cortisol (C) inhibit synthesis of testosterone ( $\mathrm{T}$ ) in body, contributing to disorders in quantity ratio of these hormones. Estimated $\mathrm{C} / \mathrm{T}$ is an indicator that reveals the exhaustion and overtraining of athlete $[8,14]$.

\section{The impact of training and competitions on cortisol level}

Several studies demonstrate relationship between the subjectively perceived stress and changes within the endocrine system of an athlete as substantial increase in level of cortisol and adrenaline and a less pronounced increase in level of testosterone $[14,15]$. Determination of cortisol and testosterone allows the assessment of prestart stress [14]. It has been shown that in athletes with higher motivation and orientation on the success, levels of these hormones were higher than those of other players. They also generally achieve better results [14].

In response to a long-lasting endurance effort, especially under conditions of low temperature and at high altitudes, an increase in cortisol level is observed [16-18]. In addition, on level of this hormone are affecting emotional factors associated with start in competition and the extreme burden and psychological exhaustion [18, 19]. It has been shown that people who experience mental depletion experience limited activity of pituitary gland and sympathetic nervous system [19].

The increase in cortisol level after exercise depends on degree of fitness of an athlete, on cultivated discipline and on volume and quality of training [20-22]. It has been demonstrated that cooling the body after training with cold water affects lowering of post-training cortisol levels as compared to the control group [22]. 


\section{Effect of nutritional components of diet on level of cortisol in blood}

The way of nourishment as well as nutrients in diet and physical activity has a decisive impact on proper functioning of body, including balance within the endocrine system.

Properly balanced diet with optional supplementation is one of the important factors determining the high physical and mental capacity of organism. Elderly people, athletes and heavy workload people often use nutritional supplementation, which makes it possible to increase efficiency and durability as well as accelerate healing process [23, 24].

These groups are particularly exposed to abnormal secretion, metabolism and transport of hormones, including cortisol. Long-term sustained high levels of cortisol in the blood are disadvantageous. This fact points to desirability of enriching daily diet with supplements, which can help to stabilize hormones.

It was shown that in stressful situations appetite for sweet and fat meals rises, probably because of their high rewarding character [25]. Consumption of meals induces increase in cortisol level. This response is strongly marked in men than in women. Influence of kind of macronutrients in taken food on cortisol concentration was investigated in many researches, but the results are not clear [26-29].

The content and type of carbohydrates in diet have a significant affect on endocrine system of active person. It was observed that the level of cortisol increases, by counteregulatory way, in response to hypoglycemia. Therefore, it is important for athletes to refill carbs before, during and after training [30]. It has been demonstrated that supplementation with $7 \%$ solutions of sugars during endurance training causes lowering of post-exercise concentration of hydrocortisone in blood while the consumption of liquids containing up to $1.5 \%$ carbohydrate or maltodextrin solutions ( $8 \%$ ) during training don't affect level of this hormone $[31,32]$.

The impact of around training protein or branched-chain amino acid (BCAA) supplementation as well as their connections with carbohydrates is not clear and requires testing on large groups of athletes of various disciplines [3238]. In case of supplementation of certain amino acids such as tryptophan, which is a precursor of serotonin, may lead to a reduction in cortisol level increase, inducted by exercise [39]. Around training administration of glutamine and arginine does not change the concentration of cortisol [32, $38,40]$.

Further nutrients, which may affect the levels of cortisol, are phospholipids: phosphatidylserine and phosphatidic acid. It has been shown that supplementation of their complex in a dose of $400 \mathrm{mg} / \mathrm{day}$ for 6 weeks resulted in

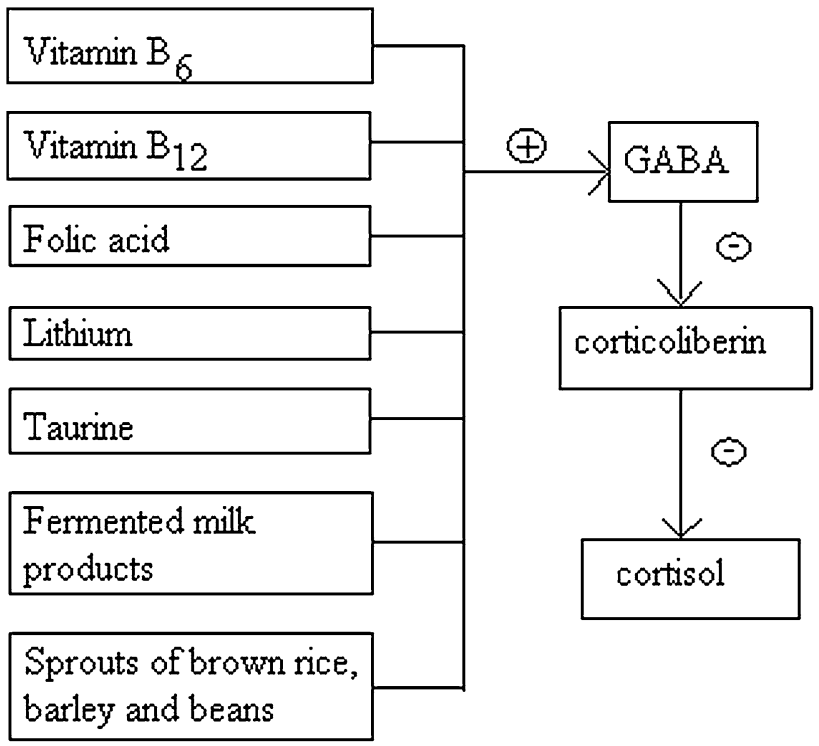

Fig. 2 Effect of food nutrients on concentration of $\gamma$-aminobutyric acid (GABA) and associated with its level of cortisol. Own elaboration based on the literature [44-50]

reducing secretion of cortisol, caused by exercise, but a dose of $200 \mathrm{mg}$ did not give a similar effect [41, 42]. Natural source of phosphatidylserine is egg yolk and of serine is protein-rich products. Serine is an endogenous amino acid and can be synthesized by organism from other amino acids. This is another reason why to maintain sufficient amounts of protein in diet of an athlete is very important [43].

A chemical compound that affects the hormonal control of cortisol is $\gamma$-aminobutyric acid (GABA). GABA reduces the secretion of corticoliberin (corticotropin-releasing hormone, $\mathrm{CRH}$ ), which triggers a series of consecutive hormonal changes, leading to secretion of cortisol by the adrenal cortex $[44,45]$. Natural sources of this substance can be fermented milk products, sprouts of brown rice, barley and beans [46, 47]. On market of dietary supplements, there are available formulations that increase the level of GABA, as well as chemically prepared $\gamma$-aminobutyric acid. However, there is evidence that use of supplements containing GABA induces side effects which haven't been observed when using a natural product [46].

Trace elements, i.e., lithium, vitamin $\mathrm{B}_{6}$, vitamin $\mathrm{B}_{12}$ and folic acid, affect on acceleration of the activity of the GABAergic system [48, 49]. Ability to stimulate the GABA receptor has the amino acid taurine [50]. GABA is produced from the amino acid glutamine in the presence of endogenous vitamin B6 [51].

Figure 2 shows the effect of nutrients and food products on GABA and cortisol concentrations. 
For many years, very popular are yoga classes. It is philosophical system of India, whose practice involves, among others, exercises, meditation or working with breath. A significant impact of yoga session on increasing concentration of GABA in brain was found [52].

\section{Dietary supplements}

Influence of ascorbic acid on level of cortisol has been widely investigated. In vitro researches demonstrated no influence of vitamin $\mathrm{C}$ on cortisol synthesis inducted by ACTH [53]. Brody et al. [54] showed that taking $3000 \mathrm{mg}$ of vitamin $\mathrm{C}$ per day leads to faster cortisol recovery after response to acute psychological stress, but it doesn't decrease overall concentration of this hormone. Numerous studies indicate that supplementation with high doses of ascorbic acid (1000-1500 mg/day) during the period preceding start of athletes in endurance disciplines hampered the growth of levels of cortisol. In addition, it contributed to reduction in muscle pain and improved efficiency of regenerative processes. A similar effect was observed when supplementation with high doses of vitamins B1, B2 and niacin, which are involved in metabolism and production of cortisol [55, 56]. Efforts were also made to link cortisol levels with vitamin $\mathrm{D}$, but the views of scientists are controversial [57, 58].

Physical exercise as a stress factor increases secretion of cortisol. In studies of Golf et al., it was demonstrated that this process can be limited by supplementation of athletes' diet with magnesium. After completion of the 14-day cycle of supplementation with $15 \mathrm{~mol}$ of magnesium was recorded lack of exercise-induced increase in cortisol level [59]. Action of magnesium is explained by its inhibitory activity on NMDA ( $N$-metil-D-aspartate) receptor, which leads to reduction in adrenocorticotropin secretion by anterior pituitary and to inhibition of cortisol synthesis at the stage of conversion of cholesterol to pregnenolone [60]. However, not all studies confirm this effect. Cinar et al. showed that the combination of magnesium supplementation $(10 \mathrm{mg} / \mathrm{kg}$ b.w.) with physical activity caused increase in cortisol concentrations. In people who only trained or were only receiving magnesium, such body's response was not found [61]. The impact of magnesium supplementation on cortisol levels in athletes is not clear and needs further investigation.

Another bioelement that affects hormonal balance is boron. In clinical study by Naghii et al. [62], it has been found that a daily morning use of preparation containing $11.6 \mathrm{mg}$ of boron, just after 1 week, results in increase in cortisol and free testosterone, dihydrotestosterone and vitamin D while decreasing estradiol levels.

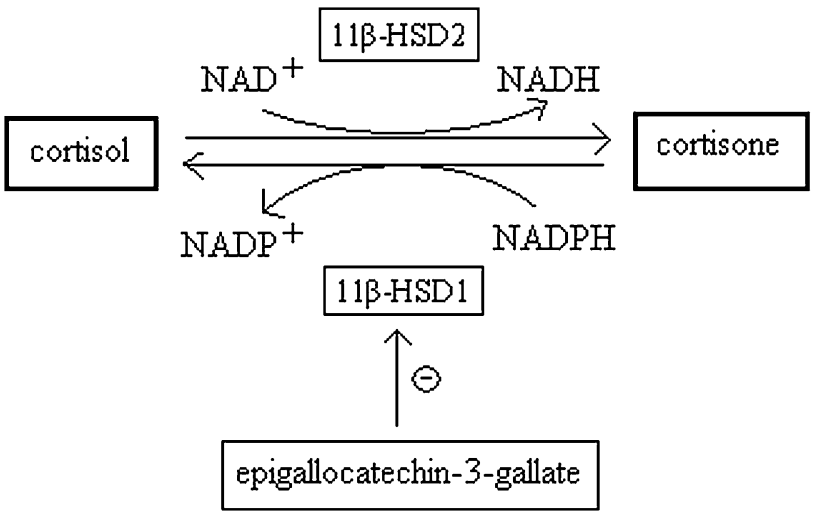

Fig. 3 Effect of epigallocatechin-3-gallate, on balance between levels of cortisol and cortisone. Own elaboration based on $[69,70]$

Supplement manufacturers often advertise preparations containing omega-3 and vitamin E, as lowering levels of cortisol, but scientific studies are not unequivocal [63-66].

It was shown that 3-week supplementation of fish oil, containing eicosapentaenoic (60 mg/day) and docosahexaenoic acid ( $252 \mathrm{mg} /$ day), reduces basal level of cortisol and subjective feeling of stress [67].

Another group of supplements widely promoted by shops with supplements with healthy food is formulations containing plant extracts. One of the plants that is commonly associated with limitation of effects of stress is lemon balm. Its positive impact on stress has been widely proved; however, discussion is whether one of the mechanisms of this action decreases level of cortisol by active compounds contained in the plant [68]. Impact of components of green tea on plasma cortisol concentration was confirmed. It was found that an epigallocatechin-3-gallate inhibits activity

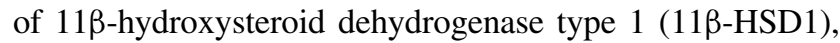
which participates in conversion of cortisone to cortisol [69, 70]. Figure 3 shows effect of epigallocatechin-3-gallate on balance between levels of cortisol and cortisone.

In a study conducted by Arent et al., it has been shown that consumption of black tea extract, enriched with theaflavin, can reduce cortisol discharge caused by stress connected with training in interval system [71]. Drinking strong infusions of turquoise oolong tea can result in a significant decrease in cortisol levels [72]. Similar effects have infusions of green coffee [73]. In contrast to the green, black coffee stimulates secretion of hydrocortisone. Studies of Gavrieli et al. [74] on cortisol levels in men who drank decaffeinated and caffeine-containing coffee showed that for the impact on level of this hormone is responsible caffeine. In addition, it was noted that included caffeine in coffee inhibits evening decrease in cortisol levels. This effect is more pronounced in younger group (15-40 years) than in older (41-70 years), regardless of gender [73-75]. 
Consumption of caffeine before a workout leads to a dose-dependent increase in both cortisol $(K)$ and testosterone $(T)$ concentrations. Supplementation with caffeine before workout can improve the $T / K$ ratio, regardless of the duration of the night's rest [76-80].

The studies concerning consumption of drinks containing carbohydrates and caffeine during workout have shown that the highest increase in cortisol levels were achieved in the group that supplemented caffeine without carbohydrates [81, 82].

Mechanism of action of caffeine on concentration of this glucocorticoid is not entirely understood. There are reports indicating stimulating effect of caffeine on gene encoding $11 \beta$-HSD2 [83]. It is also suggested that caffeine stimulates production of cortisol by adrenal glands through a direct effect on expression of StAR protein, as well as hereditary epigenetic mechanisms [75]. Some of the researchers suggest that the mechanism of caffeine effect on cortisol levels can be sex-dependent. In men, a central nervous system activity is observed, and in the case of women, additional peripheral reactions occur [77].

It was demonstrated that chronic inflammatory and immune diseases lead to resistance to anti-inflammatory action of glucocorticosteroids including cortisol [84]. Ruijters et al. showed that food-derived bioactives, because of their antioxidant activity, can protect positive functions of cortisol on inflammation process. Among the components with the biggest protective activity, there was curcumin, resveratrol, chrysin, genistein, 7-mono- $O-(\beta-$ hydroxyethyl)-rutoside and theophylline [85].

Another substance of plant origin, which may affect the level of cortisol, is betaine (trimethylglycine). It has been demonstrated that supplementation of betaine resulted in a significant decrease in amount of this hormone in organism of trained men relative to control group. Further increase in the amount of growth hormone and IGF-1 was found, indicating improved anabolic profile of patients [78].

Miyake et al. showed that supplementation with L-ornithine decreases serum cortisol level and cortisol/DHEA ratio. It also reduces anger and improves quality of sleep, which can find application in relieving sleep disorders and fatigue [86].

In recent publications appear reports about active substances contained in golden root (Rhodiola rosea), which may affect glucocorticoid receptors. Their action can have an impact on reducing the discharge of cortisol in a group of physically active people [79-81]. It has been shown that a 4-week supplementation with a standardized extract from roots of Eurycoma longifolia ("Malaysian ginseng") influences favorably on hormonal profile of respondents of both sexes. A reduction in cortisol levels by $16 \%$ and increased level of testosterone by $37 \%$ was noted. Authors suggest that the observed improvement may support sports performance $[82,83]$.
It was shown that intake of enzyme-treated asparagus extract prevents the growth of baseline cortisol level. It also raises sleep quality [87].

Among supplements advertised as increasing muscle mass and strength are formulations comprising active ingredients of plant, i.e., methyl-oxy-isoflavone, ecdysterone and sulfo-polysaccharide. Effect of the above-mentioned compounds on hormonal profile, muscle strength and lean body mass was not confirmed [88].

\section{Conclusions}

Nowadays, all people are under great pressure to achieve better results at work, sport and personal life. Mental stress in combination with physical stress contributes to formation of adverse changes in hormonal balance. Excessive levels of cortisol, which is known as the "stress hormone," leads to negative changes in body functioning. Endocrine imbalance can be reduced using a suitable way and quality of nutrition.

Demand for various nutrients is varied and dependent on gender, age, kind of work and lifestyle. The variety of produced food allows use of a varied diet, taking into account individual needs and preferences of a person.

To achieve professional and personal success, it is very important to preserve adequate nourishment. Edibles, including supplementation, have now become the subject of aggressive advertising campaigns. The necessity of consuming dietary supplements by athletes should be considered.

\section{Compliance with ethical standards}

Conflict of interest The authors declare that they have no conflicts of interest.

Compliance with ethics requirements The manuscript does not contain clinical studies or patient data.

Open Access This article is distributed under the terms of the Creative Commons Attribution 4.0 International License (http://creativecommons.org/licenses/by/4.0/), which permits unrestricted use, distribution, and reproduction in any medium, provided you give appropriate credit to the original author(s) and the source, provide a link to the Creative Commons license, and indicate if changes were made.

\section{References}

1. Ziaja J, Cholewa K, Mazurek U, Cierpka L (2008) Molecular basics of aldosterone and cortisol synthesis in normal adrenals and adrenocortical adenomas. Endokrynol Pol 4(59):330-339 
2. Buckingham JC (2006) Glucocorticoids: exemplars of multitasking. Brit J Pharmacol 147(1):258-268

3. Larsen R (2013) Anastezjologia. Elsevier Urban \& Partner, Wrocław

4. Neumeister B, Besenthal I, Böhm BO (2013) Diagnostyka laboratoryjna. Poradnik kliniczny. Elsevier Urban \& Partner, Wrocław

5. Papierska L, Rabijewski M, Misirowski W (2008) Glucocortycoid-inducted osteoporosis. Prog Med 6:389-393

6. Bornstein SR, Engeland WC, Ehrhart-Bornstein M, Herman JP (2008) Dissociation of ACTH and glucocorticoids. Trends Endocrinol Metab 19:175-180

7. Fink G (2010) Stress science: neuroendocrinology. Elselvier Inc., Oxford

8. Sapolsky RM, Romero LM, Munck AU (2000) How do glucocorticoids influence stress responses? Integrating permissive, suppressive, stimulatory, and preparative actions. Endocrinol Rev 21(1):55-89

9. Walker BR (2007) Glucocorticoids and cardiovascular disease. Eur J Endocrinol 157:545-559

10. de Sa DSF, Schulz A, Streit FE, Turner JD, Oitzl MS, Blumenthal TD, Schachinger H (2014) Cortisol, but not intranasal insulin, affects the central processing of visual food cues. Psychoneuroendocrinol 50:311-320

11. Schmid DA, Held K, Ising M, Uhr M, Weikel JC, Steiger A (2005) Ghrelin stimulates appetite, imagination of food, GH, $\mathrm{ACTH}$, and cortisol, but does not affect leptin in normal controls. Nueropsychopharmacol 30(6):1187-1192

12. Elenkov IJ, Chrousos GP (2002) Stress hormones, proinflammatory and antiinflammatory cytokines, and autoimmunity. Ann N Y Acad Sci 966:290-303

13. Grylewski A, Majcher P, Szczepanik M (2006) Immunological aspects of trauma. Post Hig 60:192-200

14. Obmiński Z (2009) Pre- and post-start hormone levels in blood as an indicator of psycho-physiological load with junior judo competitors. Pol J Sport Tourism 16:158-165

15. Salvador A, Suay F, Gonzales-Bono E, Serrano MA (2003) Anticipatory cortisol, testosterone and psychological responses to judo competition in young men. Psychoneuroendocrino 28:264-375

16. Kraemer WJ, Fragala MS, Watson G, Volek JS, Rubin MR, French DN, Maresh CM, Vingren JL, Hatfield DL, Spiering BA, Yu-Ho J, Hughes SL, Case HS, Stuempfle KJ, Lehmann DR, Bailey S, Evans DS (2008) Hormonal responses to a $160-\mathrm{km}$ race across frozen Alaska. Brit J Sport Med 42(2):116-120

17. Stuempfle KJ, Nindl BC, Kamimori GH (2010) Stress hormone responses to an ultraendurance race in the cold. Wilderness Environ Med 21(1):22-27

18. Loria P, Ottoboni S, Michelazzi L, Guiria R, Ghisellini P, Rando C, Eggenhöffner R (2014) Salivary crtisol in an extreme noncompetitive sport exercise: winter swimming. Nat Sci 6:387-398

19. Odagiri Y, Shimomitsu T, Iwane H, Katsumura T (1996) Relationships between exhaustive mood state and changes in stress hormones following an ultraendurance race. Int J Sports Med 17(5):325-331

20. Bobbert T, Mai K, Brechtel L, Schulte HM, Weger B, Pfeiffer AF, Spranger J, Diederich S (2012) Leptin and endocrine parameters in marathon runners. Int J Sports Med 33(3):244-248

21. Leite RD, Prestes J, Rosa C, De Salles BF, Maior A, Miranda H, Simão R (2011) Acute effect of resistance training volume on hormonal responses in trained men. J Sport Med Phys Fit 51(2):322-328

22. Minett GM, Duffield R, Billaut F, Cannon J, Portus MR, Marino FE (2014) Cold-water immersion decreases cerebral oxygenation but improves recovery after intermittent-sprint exercise in the heat. Scand J Med Sci Sports 24(4):656-666
23. Ziemba AW (2004) The position of the International Olympic Committee on Nutrition. Med Sport Pract 5(2/3):93-96

24. Dymkowska-Malesa M, Walczak Z (2011) Supplementation in sport. Med News 80(3):199-204

25. Zellner DA, Loaiza S, Gonzalez Z, Pita J, Morales J, Pecora D, Wolf A (2006) Food selection changes under stress. Physiol Behav 87:789-793

26. Lemmens S, Born JM, Martens EA, Martens MJ, WesterterpPlantenga MS (2011) Influence of consumption of a high-protein vs. high-carbohydrate meal on the physiological cortisol and psychological mood response in men and women. PLoS ONE 6(2):e16826

27. Peeters F, Nicholson NA, Berkhof J (2003) Cortisol responses to daily events in major depressive disorder. Psychosom Med 65:836-841

28. Martens MJ, Rutters F, Lemmens SG, Born JM, WesterterpPlantenga MS (2010) Effects of single macronutrients on serum cortisol concentrations in normal weight men. Physiol Behav. doi:10.1016/j.physbeh.2010.09.007

29. Bray GA, Most M, Rood J, Redmann S, Smith SR (2007) Hormonal responses to a fast-food meal compared with nutritionally comparable meals of different composition. Ann Nutr Metab 51:163-171

30. Rickels MR, Schutta MH, Mueller R, Kapoor S, Markmann JF, Naji A, Teff KL (2007) Glycemic thresholds for activation of counterregulatory hormone and symptom responses in islet transplant recipients. J Clin Endocrinol Metab 92:873-879

31. Ihalainen JK, Vuorimaa T, Puurtinen R, Hämäläinen I, Mero AA (2014) Effects of carbohydrate ingestion on acute leukocyte, cortisol and interleukin-6 response in high-intensity long-distance running. J Strength Cond Res 28(10):2786-2792

32. Caris AV, Lira FS, de Mello MT, Oyama LM, dos Santos RVT (2014) Carbohydrate and glutamine supplementation modulates the Th1/Th2 balance after exercise performed at a simulated altitude of $4500 \mathrm{~m}$. Nutrition 30(11-12):1331-1336

33. Betts JA, Beelen M, Stokes KA, Saris WHM, van Loon LJC (2011) Endocrine responses during overnight recovery from exercise: impact of nutrition and relationships with muscle protein synthesis. Int J Sport Nutr Exerc Metab 21(5):398-409

34. Forbes SC, McCargar L, Jelen P, Bell GJ (2014) Dose response of whey protein isolate in addition to a typical mixed meal on blood amino acids and hormonal concentrations. Int J Sport Nutr Exerc Metab 24(2):188-195

35. Hansen M, Bangsbo J, Jensen J, Bibby BM, Madsen K (2015) Effect of whey protein hydrolysate on performance and recovery of top-class orienteering runners. Int J Sport Nutr Exerc Metab 25(2):97-109

36. Betts JA, Stokes KA, Toone RJ, Williams C (2013) Growthhormone responses to consecutive exercise bouts with ingestion of carbohydrate plus protein. Int J Sport Nutr Exerc Metab 23(3):259-270

37. Hoffman JR, Ratamess NA, Kang J, Rashti SL, Kelly N, Gonzalez AM, Stec M, Anderson S, Bailey BL, Yamamoto LM, Hom LL, Kupchak BR, Faigenbaum AD, Maresh CM (2010) Examination of the efficacy of acute L-alanyl-L-glutamine ingestion during hydration stress in endurance exercise. J Int Soc Sports Nutr 7(12):8-20

38. Carol A, Witkamp RF, Wichers HJ, Mensink M (2011) Bovine colostrum supplementation's lack of effect on immune variables during short-term intense exercise in well-trained athletes. Int $\mathbf{J}$ Sports Nutr Exerc Metab 21(2):135-145

39. Capello AE, Marcus CR (2014) Effect of sub chronic tryptophan supplementation on stress-induced cortisol and appetite in subjects differing in 5-HTTLPR genotype and trait neuroticism. Psychoneuroendocrinology 45:96-107 
40. Alvares TS, Conte-Junior CA, Silva JT, Paschoalin VMF (2014) L-arginine does not improve biochemical and hormonal response in trained runners after 4 weeks of supplementation. Nutr Res 34(1):31-39

41. Hellhammer J, Vogt D, Franz N, Freitas U, Rutenberg D (2014) A soy-based phospatidyloserine/phosphatidic acid complex (PAS) normalizes the stress reactivity of hypothalamus-pituaryadrenal-axis in chronically stressed male subjects: a randomized, placebo-controlled study. Lipids Health Dis 13:121

42. Starks MA, Starks SL, Kingsley M, Purpura M, Jager R (2008) The effects of phosphatidylserine on endocrine response to moderate intensity exercise. J Int Soc Sports Nutr 5(6):11-17

43. Siepka E, Bobak $€$, Gładkowski W (2015) Characteristics of the biological activity of egg yolk phospholipids. Żywn Nauk Technol Jakość 2(99):15-28

44. Pawlaczyk B (2010) The role of hormones in the regulation of human body homeostasis. Homines Hominibus 6:7-20

45. Miklos IH, Kovacs KJ (2002) GABAergic innervation of corticotropin-releasing hormone (CRH)-secreting parvocellular neurons and its plasticity as demonstrated by quantitative immunoelectron micorscopy. Neurosci 113(3):581-592

46. Szosland-Fałtyn A, Królasik J (2014) Fermented dairy as a source of gamma aminobutyric acid. Food Ind 68(10):30-32

47. Lewicki PP (2010) Sprouted seeds as a source of valuable nutrients. Food Sci Technol Qual 6(73):18-33

48. Długaszek M, Kłos A, Bertrandt J (2012) Lithium supply in the daily food rations of students. Prob Hig Epidemiol 93(4):867-870

49. Kalea A, Naphadeb N, Sapkaleb S, Kamarajub M, Pillaic A, Joshia S, Mahadikc S (2010) Reduced folic acid, vitamin B12 and docosahexaenoic acid and increased homocysteine and cortisol in never-medicated schizophrenia patients: implications for altered one-carbon metabolism. Psychiatr Res 175(1-2):47-53

50. Song Z, Hatton GI (2003) Taurine and the control of basal hormone release from rat neurophysis. Exp Neurol 183:330-337

51. Cichosz G, Czeczot H (2013) Controversions around diet proteins. Pol Med J 35(210):397-401

52. Streeter CC, Whitfield TH, Owen L, Rein T, Karri SK, Yakhkind A, Permutter R, Prescot A, Renshaw PF, Ciraulo DA, Jensen JE (2010) Effects of yoga versus walking on mood, anxiety, and brain GABA levels: a randomized controlled MRS study. J Altern Complement Med 16:1145-1152

53. Monotalvo CP, Díaz NH, Galdames LA, Andrés ME, Larraín RE (2011) Short communication: effect of vitamins E and C on cortisol production by bovine adrenocortical cells in vitro. J Dairy Sci 94(7):3495-3497

54. Brody S, Preut R, Schommer K, Schürmeyer TH (2002) A randomized controlled trial of high dose ascorbic acid for reduction of blood pressure, cortisol and subjective responses to psychological stress. Psychopharmacology 159(3):319-423

55. Tauler P, Martinez S, Martinez P, Moreno C, Monjo M, Aguil A (2014) Vitamin C supplementation does not influence plasma and blood mononuclear cell IL-6 and IL-10 levels after exercise. J Sports Sci 32(17):1659-1669

56. Diaz E, Ruiz F, Hoyos I, Zubero J, Gravina L, Gil J, Irazusta J, Gil SM (2010) Cell damage, antioxidant status, and cortisol levels related to nutrition in ski mountaineering during a two-day race. J Sci Med 9(2):338-346

57. Muscogiuri G, Altieri B, Penna-Matrinez M, Badenhoop K (2015) Focus on vitamin D and the adrenal gland. Horm Metab Res 47(4):239-246

58. Arora CP, Chatta P, Hobel CJ (2012) High cortisol (stress) levels during pregnancy are correlated with low levels of $25(\mathrm{OH})$ vita$\min$ D. Reprod Sci 19(3):173A

59. Golf SW, Happel O, Graef V, Seim KE (1984) Plasma aldosterone, cortisol and electrolyte concentrations in physical exercise after magnesium supplementation. J Clin Chem Clin Biochem 22(11):717-721

60. Abbasi B, Kimiagar M, Sadeghniiat K, Shirazi MM, Hedayati M, Rashidkhani B (2012) The effect of magnesium supplementation on primary insomnia in elderly: a double-blind placebocontrolled clinical trial. J Res Med Sci 17(12):1161-1169

61. Cinar V, Mogulkoc R, Baltacj AK, Polat Y (2008) Adrenocorticotropic hormone and cortisol levels In athletes and sedentary subjects AT rest and exhaustion: effects of magnesium supplementation. Biol Trace Elem Res 121(3):215-220

62. Naghii MR, Mofid M, Asgari AR, Hedayati M, Daneshpour MS (2011) Comparative effects of daily and weekly boron supplementation on plasma steroid hormones and proinflammatory cytokines. J Trace Elem Med Biol 25(1):54-58

63. McAnultya SR, McAnultyb LS, Niemana DC, Morrowd JD, Shootera LA, Holmesb S, Hewarde Ch, Hensonc DA (2005) Effect of alpha-tocopherol supplementation on plasma homocysteine and oxidative stress in highly trained athletes before and after exhaustive exercise. J Nut Biochem 16(9):530-537

64. Jazayeria S, Keshavarza SA, Tehrani-Doostb M, Djalalia M, Hosseinic M, Aminib H, Chamaria M, Djazayerya A (2010) Effects of eicosapentaenoic acid and fluoxetine on plasma cortisol, serum interleukin-1 beta and interleukin-6 concentrations in patients with major depressive disorder. Psychia Res 178(1):112-115

65. Tsitouras PD, Gucciardo F, Salbe AD, Heward C, Harman SM (2008) High omega-3 fat intake improves insulin sensitivity and reduces CRP and IL6, but does not affect other endocrine axes in healthy older adults. Horm Metab Res 40:199-205

66. Eric E, Noreen EE, Sass MJ, Crowe ML, Pabon VA, Brandauer J, Averill LK (2010) Effects of supplemental fish oil on resting metabolic rate, body composition, and salivary cortisol in healthy adults. J Int Soc Sport Nutr 7:31-38

67. Barbadoro P, Annino I, Ponzio E, Romanelli RM, D'Errico MM, Prospero E, Minelli A (2013) Fish oil supplementation reduces cortisol basal levels and perceived stress: a randomized, placebo-controlled trial in abstinent alcohilics. Mol Nutr Food Res 57(6):1110-1114

68. Scholey A, Gibbs A, Neale Ch, Perry N, Ossoukhova A, Bilog V, Kras M, Scholz C, Sass M, Buchwald-Werner S (2014) Anti-stress effects of lemon balm-containing foods. Nutrients 6(11):4805-4821

69. Hitzpeter J, Stapelfeld C, Loerz Ch, Martion HJ, Maser E (2014) Green tea and one of its constituents, epigallocatechine-3-gallate, are potent inhibitors of human $11 \beta$-hydroxysteroid dehydrogenase type 1. PLoS ONE 9(1):1-9

70. Szelényi P, Révész K, Konta L, Tüttõ A, Mandl J, Kereszturi E, Csala M (2013) Inhibition of microsomal cortisol production by (-)-epigallocetechin-3-gallate through a redox shift in the endoplasmic reticulum - a potential new target for treating obesityrelated diseases. Int Union Biochem Mol Biol 39(5):534-541

71. Arent SM, Senso M, Golem DL, McKeever KH (2010) The effects of theaflavin-enriched black tea extract on muscle soreness, oxidative stress, inflammation, and endocrine responses to acute anaerobic interval training: a randomized, double-blind, crossover study. J Int Soc Sports Nutr 23:7-10

72. Kurihara H, Chen L, Zhu BF, He ZD, Shibata H, Kiso Y, Tanaka T, Yao XS (2003) Anti-stress effect of oolong tea in women loaded with virgil. J Health Sci 49(6):436-443

73. Revuelta-Iniesta R, Al-Dujaili EAS (2014) Consumption of green coffee reduces blood pressure and body composition by influencing 11 beta-HSD1 enzyme activity in healthy individuals: a pilot crossover study using green and black coffee. Biomed Res Int. doi:10.1155/2014/482704

74. Gavrieli A, Yannakoulia M, Fragopoulou E, Margaritopoulos D, Chamberland JP, Kaisari P, Kavouras SA, Mantzoros ChS (2011) 
Caffeinated coffee does not acutely affect energy intake, appetite or inflammation but prevents serum cortisol concentrations from falling in healthy men. J Nutr 19:703-707

75. Ping J, Lei YY, Liu L, Wang TT, Feng YH, Wang H (2012) Inheritable stimulatory effects of caffeine on steroidogenic acute regulatory protein expression and cortisol production in human adrenocortical cells. Chem Biol Interact 195(1):68-75

76. Beaven CM, Hopkins WG, Hansen KT, Wood MR, Cronin JB, Lowe TE (2008) Dose effect of caffeine on testosterone and cortisol responses to resistance exercise. Int J Sport Nutr Exerc Metab 18(2):131-141

77. Lovallo WR, Farag NH, Vincent AS, Thomas TL, Wilson MF (2006) Cortisol responses to mental stress, exercise, and meals following caffeine intake in men and women. Pharmacol Biochem Behav 83(3):441-447

78. Apicella JM, Lee EC, Bailey BL, Saenz C, Anderson JM, Craig SAS, Kraemer WJ, Volek JS, Maresh CM (2013) Betaine supplementation enhances anabolic endocrine and Akt signaling in response to acute bouts of exercise. Eur J Appl Physiol 113(3):793-802

79. Olsson EM, von Schéele B, Panossian AG (2009) A randomised, double-blind, placebo-controlled, parallel-group study of the standardised extract shr-5 of the roots of Rhodiola rosea in the treatment of subjects with stress-related fatigue. Planta Med 75(2):105-112

80. Jurcău R, Jurcău I, Bodescu C (2012) Anxiety and salivary cortisol modulation in exercise induced stress, using a phytotherapic product containing Rhodiola rosea. Palestr Third Mill Civiliz Sport 13(3):213-217

81. Zhang ZJ, Tong Y, Zou J, Chen PJ, Yu DH (2009) Dietary supplement with a combination of Rhodiola crenulata and Ginkgo biloba enhances the endurance performance in healthy volunteers. Chin J Integr Med 15(3):177-183

82. Lee CL, Cheng CF, Astorino TA, Lee CJ, Huang HW, Chang WD (2014) Effects of carbohydrate combined with caffeine on repeated sprint cycling and agility performance in female athletes. J Int Soc Sports Nutr 11(12): 17

83. Talbott SM (2014) Human performance and sports applications of Tongkat Ali (Eurycoma longifolia). In: Bagchi D, Nair S, CK Sen (eds) Nutrition and enhanced sports performance. Elsevier Inc

84. Barnes PJ, Adcock IM (2009) Glucocorticoid resistance in inflammatory diseases. Lancet 373:1905-1917

85. Ruijters EJB, Haenen GRMM, Willemsen M, Weseler AR, Bast A (2016) Food-derived bioactivies can protect the antiinflammatory activity of cortisol aith antioxidant-dependent and -independent mechanism. Int J Mol Sci 17:239. doi:10.3390/ ijms17020239

86. Miyake M, Morishita K, Kamura H, Tsuda A, Kirisako T, Kokubo T, Miura Y (2014) Randomised controlled trial of the effects of L-ornithine on stress markers and sleep quality in healthy workers. Nutr J. doi:10.1186/1475-2891-13-53

87. Ito T, Goto K, Takanari J, Miura T, Wakame K, Nishioka H, Tanaka A, Nishihira J (2014) Effects of enzyme-treated asparagus extract on heat shock protein 70, stress indices, and sleep in healthy adult men. J Nutr Sci Vitaminol 60(4):283-290

88. Wilborn CD, Taylor LW, Campbell BI, Kerksick Ch, Rasmussen ChJ, Greenwood M, Kreider RB (2006) Effects of methoxyisoflavone, ecdysterone, and sulfo-polysaccharide supplementation od training adaptations in resistance-trained males. J Int Soc Sports Nutr 3(2):19-27 